University of Nebraska - Lincoln

DigitalCommons@University of Nebraska - Lincoln

4-1985

\title{
Fat Deposition and Usage by Arctic-Nesting Sandhill Cranes During Spring
}

\author{
Gary Krapu \\ USGS Northern Prairie Wildlife Research Center, gkrapu@usgs.gov \\ George Iverson \\ USGS Northern Prairie Wildlife Research Center \\ Kenneth Reinecke \\ USGS Northern Prairie Wildlife Research Center \\ Cheryl Boise \\ USGS Northern Prairie Wildlife Research Center
}

Follow this and additional works at: https://digitalcommons.unl.edu/usgsnpwrc

Part of the Other International and Area Studies Commons

Krapu, Gary; Iverson, George; Reinecke, Kenneth; and Boise, Cheryl, "Fat Deposition and Usage by ArcticNesting Sandhill Cranes During Spring" (1985). USGS Northern Prairie Wildlife Research Center. 46.

https://digitalcommons.unl.edu/usgsnpwrc/46

This Article is brought to you for free and open access by the US Geological Survey at DigitalCommons@University of Nebraska - Lincoln. It has been accepted for inclusion in USGS Northern Prairie Wildlife Research Center by an authorized administrator of DigitalCommons@University of Nebraska - Lincoln. 


\title{
FAT DEPOSITION AND USAGE BY ARCTIC-NESTING SANDHILL CRANES DURING SPRING
}

\author{
Gary L. Krapu, ${ }^{1}$ George C. IVerson, ${ }^{2}$ Kenneth J. Reinecke, ${ }^{1}$ \\ AND CHERYL M. BOISE ${ }^{3}$ \\ ${ }^{1}$ U.S. Fish and Wildlife Service, Northern Prairie Wildlife Research Center, P. O. Box 1747, \\ Jamestown, North Dakota 58401 USA, \\ ${ }^{2}$ Oklahoma Cooperative Wildlife Research Unit, 404 Life Sciences West, Oklahoma State University, \\ Stillwater, Oklahoma 74078 USA, and \\ ${ }^{3}$ Alaska Cooperative Wildlife Research Unit, Fairbanks, Alaska 99701 USA
}

\begin{abstract}
Body weight, fat, and protein levels of arctic-nesting Sandhill Cranes (Grus canadensis) were measured at several locations during spring migration and on the breeding grounds. Body weights of adult males and females increased by about $34 \%(1,129 \mathrm{~g})$ and $30 \%$ $(953 \mathrm{~g})$ from early March at the Platte River to late April at Last Mountain Lake, Saskatchewan; average fat content increased from about 250 to $990 \mathrm{~g}$. Rates of weight gain and fat deposition among males and females averaged 25-18 and 16-13 g/day. Body weights and fat content of cranes staging along the North Platte River followed similar patterns and usually were higher than along the Platte River during comparable periods. Fat reserves of paired cranes collected after their arrival at a major breeding ground on the Yukon-Kuskokwim Delta in western Alaska averaged about $530 \mathrm{~g}$, or about $46 \%$ less than peak fat content in Saskatchewan. Patterns of weight increase and fat deposition in cranes during migration were similar to those previously described for northern-nesting geese, except that nutrient storage is not sex specific in cranes. Body protein of adult female cranes did not change significantly during spring migration $(P=0.28)$. Female cranes allocate less nutrients to clutch formation in proportion to body size than do northern-nesting geese. Received 6 April 1984, accepted 29 October 1984.
\end{abstract}

CERTAIN waterfowl have evolved successful breeding strategies in arctic environments partly through physiological adaptations that allow nutrients stored during spring migration to be utilized during reproduction. In northern-nesting geese, for example, nearly all the nutrients required to lay and incubate a clutch are carried to the breeding grounds (Ankney and MacInnes 1978, Raveling 1979). Moreover, the ability of females to store nutrients is thought to be the primary factor regulating clutch size in several species (Ryder 1970, Raveling and Lumsden 1977, Davies and Cooke 1983). Although Sandhill Cranes (Grus canadensis) also breed widely in the Arctic, the extent of nutrient storage during spring migration and the contribution of nutrient reserves to reproduction is poorly understood, prompting this investigation. In this paper, we describe temporal patterns of body weight, fat, and protein content in Sandhill Cranes during spring and compare nutrient storage and utilization patterns among northern-nesting populations of cranes and geese.

\section{STUdY AREA AND METHODS}

Arctic-nesting populations of the Sandhill Crane breed from the Hudson Bay region in Canada westward to western Alaska and eastern Siberia (Walkinshaw 1949). The wintering grounds of the midcontinent population are primarily in the south-central United States (Texas and New Mexico) and Mexico. Spring migration lasts about 2 months, including a 4-6-week stopover each year in the Platte or North Platte river valleys in Nebraska.

Collections of Sandhill Cranes were made in the Platte River Valley, the Last Mountain Lake area of Saskatchewan, and on the Clarence Rhode National Wildlife Range (NWR) on the Yukon-Kuskokwim Delta in western Alaska. Detailed descriptions of these areas have been presented as follows: the Platte River Valley by Krapu et al. $(1982,1984)$, the Last Mountain Lake area by Stephen (1967), and the Yukon-Kuskokwim. Delta by Mickelson (1975) and Boise (1977) Sandhill Cranes were obtained by shooting during the spring stopover period in the Platte Valley from late February to mid-April in 1978 and 1979, at Last Mountain Lake in central Saskatchewan during late April in 1978 and 1979, and on the breeding grounds at the Clarence Rhode NWR on the Yukon-Kuskokwim Delta near Old Chevak, Alaska during May in 
1978 and 1979. Birds collected at the latter site were paired and territorial. Nebraska and Saskatchewan staging areas are used by the western Alaska breeding population as indicated by sightings of colormarked birds (T. C. Tacha unpubl. data).

Migrant specimens were collected (usually one per flock) and taken to field laboratories where wet body weight (g), flattened wing chord ( $\mathrm{mm}$ ), tarsus length (mm), and culmen length ( $\mathrm{mm}$, post nares and exposed) were measured to determine subspecies following criteria in Johnson and Stewart (1973). Specimens of Greater Sandhill Cranes (G. c. tabida) and Canadian Sandhill Cranes (G. c. rowani), which breed southward from the Arctic, were excluded from these analyses, restricting the sample to Lesser Sandhill Cranes (G. c. canadensis). Adults were distinguished from immatures (young of the previous year) by the lack of brown feathering on the occiput (Lewis 1979). Sex and reproductive status were determined by gonadal examination.

In preparation for nutrient analysis, we removed all esophageal and gizzard contents, plucked each bird, reweighed the featherless carcass to the nearest gram, and homogenized the carcass in a commercial meat grinder. Measurement of lipid content in carcasses followed standard procedures (Horwitz 1975). All analyses were on the whole-carcass homogenate. Lipid content was determined by Soxhlet extraction using petroleum ether, with duplicate analyses for each specimen. Protein determination was by the Kjeldahl method (Horwitz 1975).

Crane fat levels were also determined from collections made by personnel of the Oklahoma Cooperative Wildlife Research Unit in the North Platte River Valley during March-April in 1979 and 1980, Last Mountain Lake, Saskatchewan, April 1980, and during May 1980 at Delta Junction, a temporary stopover area in eastern Alaska, and on the Yukon-Kuskokwim Delta. A detailed description of methods is presented by Iverson (1981).

The extent of foraging by Sandhill Cranes during the breeding season on the Yukon-Kuskokwim Delta was determined in 1979 using methods described by Wiens et al. (1970). Crane activity was sampled at 12-s intervals between 0400 and 2300 from blinds. A total of $8.7 \mathrm{~h}(2,592$ observations) and $8.2 \mathrm{~h}(2,450$ observations) was obtained between arrival and the onset of incubation by adult males and females, respectively. Observations were restricted to pairs on territories and began on 5 May. Sex of paired individuals was determined from differences in unison calls (Archibald 1976).

All test statistics were computed with the Statistical Analysis System (Barr et al. 1979). The slopes of linear regressions of body weight and fat on Julian date were used to estimate rates of weight gain and fat deposition. Means are presented as $\bar{x} \pm \mathrm{SD}(n)$ in the text and Table 1.

\section{RESULTS}

\section{Chronology of Migration}

Sandhill Cranes usually begin arriving at the Platte River in late February and the population gradually builds until reaching a peak during mid- to late March. Radio-tagged birds in 1978 (6) and 1979 (14) stayed an average of 26 and 32 days after radios were attached in late February and early March, respectively (Krapu unpubl. data). The population of about one-half million cranes occupy about $1,036 \mathrm{~km}^{2}$ of valley during the day and at night roost in about $111 \mathrm{~km}$ of channel in the Platte and North Platte rivers (Krapu et al. 1982). The days are spent foraging and resting on grassland, alfalfa hayland, and cropland near the river (Krapu et al. 1984).

Sandhill Cranes depart from the Nebraska staging areas in early to mid-April. Most leave within a few days after the first flocks initiate migration. Following their stay in the Platte Valley, the birds continue northward, stopping only briefly until reaching the prairie pothole country of Saskatchewan and eastern Alberta. Upon arrival in prairie Canada, the birds roost primarily in natural basin wetlands and forage on nearby agricultural lands. In late April and early May, the cranes depart for northern breeding grounds including the Yukon-Kuskokwim Delta where they arrive from early to mid-May (Boise 1977).

\section{BODY WEIGHT PATteRNS}

Body weights of adult male and adult female Sandhill Cranes increased by an estimated 34 and $30 \%$ from arrival at the Platte River to departure from Last Mountain Lake (5 March to 28 April; Table 1). Male and female cranes collected early in the stopover period along the Platte River in Nebraska (5-14 March) weighed 3,309 and 3,135 g, respectively (Table 1). By 25 March to 3 April, average body weights of sampled males and females were 3,855 and 3,330 g. Body weights of males and females collected from early March to mid-April along the North Platte River exhibited a similar pattern of weight gain as occurred along the Platte River (Table 1). Body weights of males and females collected near the end of the stopover at the Last Mountain Lake area in Saskatchewan (24- 


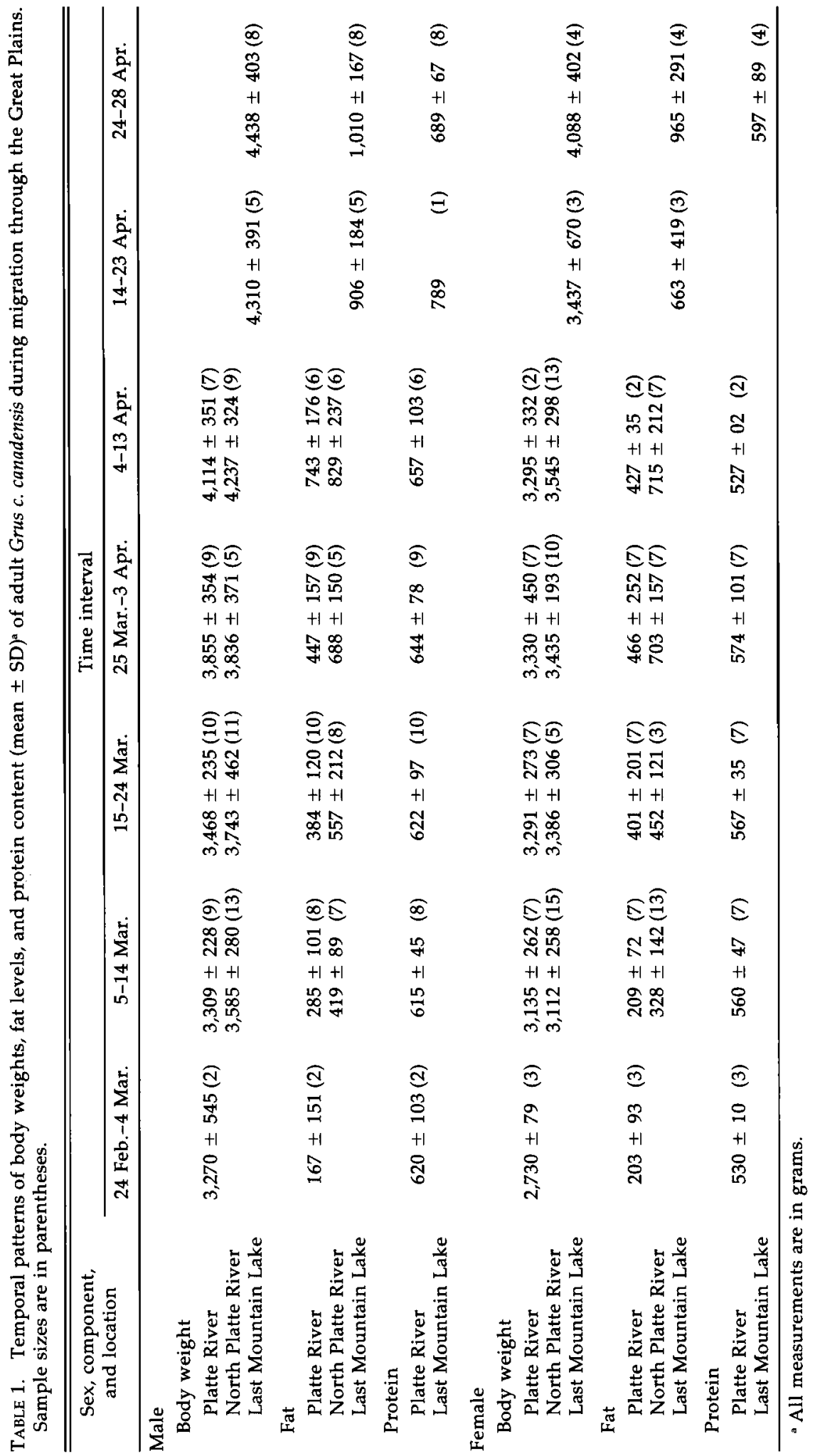


28 April) averaged 4,438 and $4,088 \mathrm{~g}$. The estimated average daily increments of weight gain among males (45) and females (33) were 24.5 and $17.8 \mathrm{~g}$ during the interim from arrival along the Platte River to departure from the vicinity of Last Mountain Lake (males: $Y=1,637.6+$ 24.5X, $F=94.3, P<0.0001$; females: $Y=$ $1,805.4+17.8 X, F=30.6, P<0.0001)$.

Body weights of paired adult males and adult females collected during 2-10 May on the Yukon-Kuskokwim Delta were 19 and $17 \%$ less than recorded at departure from Saskatchewan. Paired males averaged $3,593 \pm 342 \mathrm{~g} \mathrm{(8)}$, and females $3,398 \pm 337 \mathrm{~g}(8)$.

\section{BODY COMPOSTION}

Spring migration.-Sandhill Cranes are relatively lean upon arrival at the Platte River. Fat content (as a percent of wet body weight) of early-arriving adult males and adult females averaged $5 \%(2)$ and $8 \%(3 ; 24$ February to 4 March), and $10 \%(8)$ and $8 \%(7 ; 5-14$ March), respectively. In absolute values, fat of males and females averaged 167 and $203 \mathrm{~g}$ (24 February to $4 \mathrm{March}$ ), and 285 and $209 \mathrm{~g}$ (5-14 March; Table 1). At departure from Nebraska (4-13 April), fat content of sampled males and females averaged 743 and $427 \mathrm{~g}$, respectively (Table 1). The low fat content of females late in the staging interval along the Platte River probably is due to sampling error. During the interval between arrival in Nebraska (5-14 March) and departure from Saskatchewan (2428 April), cranes gained an average of about $740 \mathrm{~g}$ of fat. Fat content of males and females collected in Saskatchewan during 24-28 April just prior to their departure averaged 1,010 and $965 \mathrm{~g}$, respectively (Table 1), or 25 and $24 \%$ of wet body weight. The estimated daily increments of fat gain among males (45) and females (33) were 15.9 and $12.6 \mathrm{~g}$ during the interim from arrival along the Platte River to departure from Last Mountain Lake in late April (males: $\hat{Y}=-856.5+15.9 X, F=152.2, P<0.0001$; females: $\hat{Y}=-626.9+12.6 X, F=46.1, P<$ $0.0001)$. Fat levels were significantly higher among males than females $(P<0.05)$ and proportional to lean body mass.

Fat levels among cranes distributed along the North Platte River exceeded levels among cranes at the Platte River during comparable periods (Table 1). Fat content of adult males and adult females sampled along the North
Platte River averaged $12 \%$ (7) and $11 \%$ (13) during 5-14 March and 20\% (6) and 20\% (7) during 4-13 April. In absolute values, fat levels of males and females averaged 413 and $328 \mathrm{~g}$ during 5 14 March and 829 and $715 \mathrm{~g}$ during 4-13 April (Table 1).

Protein levels of adult males and adult females during 5-14 March at the Platte River averaged 615 and $560 \mathrm{~g}$, respectively, and 689 and $597 \mathrm{~g}$ during 24-28 April at the end of their stay at Last Mountain Lake (Table 1). Body protein content of adult males increased significantly during the period of spring migration through the Great Plains region $(F=5.9$, $\mathrm{df}=45, P=0.02$ ), but protein levels of females did not change significantly $(F=1.2, \mathrm{df}=33$, $P=0.28$ ).

Breeding grounds.-Paired adult male and adult female Sandhill Cranes collected on the $\mathrm{Yu}$ kon-Kuskokwim Delta during 2-10 May averaged $492 \pm 239 \mathrm{~g} \mathrm{(8)}$ and $569 \pm 135 \mathrm{~g}(8)$ of fat, 51 and $41 \%$ less than recorded among cranes sampled during 24-28 April at Last Mountain Lake. The sample of adult males from the Yukon-Kuskokwim Delta included one highly emaciated bird that contained only $66 \mathrm{~g}$ of fat. A significant part of fat loss probably occurred during the interval between arrival on the breeding grounds and collection. This interpretation is supported by data on the lipid content of cranes collected at Delta Junction about $700 \mathrm{~km}$ east of the nesting grounds. Adult male and adult female cranes sampled at Delta Junction during 30 April to 8 May 1980 averaged $891 \pm 91 \mathrm{~g}(7)$ and $822 \pm 260 \mathrm{~g}(2)$ of lipids, respectively, suggesting that a relatively high percentage of the fat deposited on staging areas in the Great Plains remains as the birds approach the breeding grounds. Protein levels of males and females collected on the Yukon-Kuskokwim Delta during 2-10 May averaged $646 \pm 11 \mathrm{~g}(3)$ and $544 \pm 55 \mathrm{~g}$ (4), respectively.

The amount of nutrients deposited in a clutch by a female crane relative to its body size is substantially less than occurs among temperate and arctic-nesting geese (Table 2). At most, 10\% of the lipids carried by cranes to the breeding grounds are channeled into egg formation. Cranes were observed foraging regularly after their arrival on the breeding grounds, but total food intake probably is often low early in the season because of limited food availability. Snow frequently is present when the cranes arrive there. Males and females under obser- 
TABLE 2. Relationships between body weight, fat reserves, egg size, and clutch size of female Lesser Sandhill Cranes and northern-nesting geese.

\begin{tabular}{|c|c|c|c|c|c|c|}
\hline Species & $\begin{array}{c}\text { Fat reserves } \\
\text { (\% of } \\
\text { prelaying } \\
\text { weight) }\end{array}$ & $\begin{array}{c}\text { Winter } \\
\text { weight } \\
\text { of adult } \\
\text { female }(g)\end{array}$ & $\begin{array}{c}\text { Average } \\
\text { egg weight } \\
\text { (g) }\end{array}$ & $\begin{array}{c}\text { Egg weight } \\
\text { (\% of } \\
\text { winter } \\
\text { weight) }\end{array}$ & $\begin{array}{c}\text { Average } \\
\text { clutch size }\end{array}$ & $\begin{array}{c}\text { Average } \\
\text { clutch } \\
\text { weight (\% } \\
\text { of winter } \\
\text { weight) }\end{array}$ \\
\hline $\begin{array}{l}\text { Grus c. canadensis } \\
\text { Branta canadensis }\end{array}$ & 16 & 3,017 & 150 & 5.0 & 1.8 & 8.9 \\
\hline $\operatorname{minima}^{a}$ & 28 & 1,205 & 97 & 8.0 & 5.0 & 40.3 \\
\hline B. c. maxima ${ }^{\mathrm{b}}$ & $29 c$ & 3,970 & 168 & 4.2 & 5.4 & 22.9 \\
\hline B. c. interior ${ }^{\mathrm{b}}$ & - & 3,400 & 159 & 4.7 & 4.5 & 21.0 \\
\hline B. c. parvipes ${ }^{b}$ & - & 1,870 & 104 & 5.6 & $3.9-4.3$ & $21.7-23.7$ \\
\hline B. bernicla ${ }^{\mathrm{b}}$ & - & 1,375 & 91 & 6.7 & 3.9 & 25.8 \\
\hline Chen caerulescens ${ }^{\mathrm{b}}$ & - & 2,565 & 129 & 5.0 & 4.4 & 22.1 \\
\hline Anser rossit & - & 1,550 & 91 & 5.9 & 3.7 & 21.7 \\
\hline
\end{tabular}

a Raveling (1979).

b Raveling and Lumsden (1977: Table 41).

' McLandress and Raveling (1981).

vation spent 16 and $28 \%$ of the time feeding between arrival and the onset of incubation. In early May, cranes were observed foraging in heath, and at frozen slough and pond edges at mid- to low tides. By late May, feeding was observed at upland tundra sites in low marshes interspersed within the heath.

\section{DisCussion}

The timing and percentage of weight and fat increase by Sandhill Cranes during early spring are similar to patterns observed in certain species and subspecies of geese. In both cranes and geese, peak fat levels averaged $20-30 \%$ of body weight. Weight gains in the Giant Canada Goose (Branta canadensis maxima) from late February to early April averaged about 26 and $36 \%$ among males and females, respectively (McLandress and Raveling 1981). Fat contributed $89 \%$ of $691 \mathrm{~g}$ gained by males and $75 \%$ of 1,091 $\mathrm{g}$ gained by females. Weight gains occurred prior to northward migration. These geese breed within about $800 \mathrm{~km}$ of wintering areas and do not utilize traditional staging areas during spring migration as do cranes and other geese. Among Cackling Canada Geese (B. $c$. minima), which also breed on the Yukon-Kuskokwim Delta, body weights of males and females increased by 26 and $46 \%$, and fat by 88 and $209 \%$, respectively, between departure from wintering areas in April and arrival on the nesting grounds (Raveling 1979). Snow Geese (Chen caerulescens) fatten during a 2-month mi- gration from the Gulf Coast to their nesting grounds near Hudson Bay (Wypkema and Ankney 1979, Ankney 1982). A primary difference between nutrient deposition patterns of northern-nesting cranes and geese is the lack of sexspecific nutrient storage in cranes. Female geese characteristically gain more weight and store larger fat and protein reserves prior to nesting than do males (Ankney and MacInnes 1978, Raveling 1979, McLandress and Raveling 1981).

To gain a better understanding of the energy costs and potential fat usage by cranes during the interval between departure from the northern Great Plains to arrival on the breeding grounds, we compared observed patterns of fat usage by cranes to estimates of the energy requirement for migration calculated with Eq. 5.47 from Kendeigh et al. (1977: 163). Assuming that a $4.0-\mathrm{kg}$ crane departs the Last Mountain Lake area on a flight of $3,500 \mathrm{~km}$ to western Alaska, the energy cost would be about $4,349 \mathrm{kcal}$ $(18,211 \mathrm{~kJ})$. If a gram of stored fat containing $9.45 \mathrm{kcal}$ (39.57 kJ; Ricklefs 1974) yields $90 \%$ of its energy when mobilized, then about $511 \mathrm{~g}$ of fat are needed for migration. If we assume the duration of migration from Last Mountain Lake to western Alaska to be 7 days, existence metabolism would equal $2,436 \mathrm{kcal}(10,201 \mathrm{~kJ})$. Without any foraging enroute, about $287 \mathrm{~g}$ of additional fat would be required to meet the existence energy requirements. Based upon our data on fat levels at Delta Junction, cranes appear to have used substantially less fat reserves for migration than our projected estimate, 
probably due, in part, to energy conserved by soaring flight (see Pennycuick et al. 1979) and some additional foraging at temporary stopovers while enroute to the breeding grounds from Saskatchewan.

Female cranes allocate less nutrients to clutch formation relative to body size than do northern-nesting geese. The weight-specific egg size of Sandhill Cranes is comparable to that of waterfowl but smaller than many birds (Table 2; Ricklefs 1974: Table 11). The combination of small egg and small clutch size results in a relatively low allocation of nutrients to clutch formation (Table 2). Current theory suggests that survival rates are associated with residual reproductive values (Pianka and Parker 1975). Cranes have high survival rates (Johnson 1979) and so would be expected to invest less in current reproduction than species with a lower expectation of future offspring.

Partitioning part of the energy requirements for reproduction to migrational stopovers results in peak daily energy demands on stopovers to be higher than after the birds arrive on the breeding grounds. For purposes of illustration, we assumed that a gram of fat contains $9.45 \mathrm{kcal}(39.57 \mathrm{~kJ})$ and that $75 \%$ is a reasonable efficiency for productive processes (Ricklefs 1974: 171). A 3.5-kg crane synthesizing $13 \mathrm{~g}$ of fat/day would then require about $163.8 \mathrm{kcal}(685.8 \mathrm{~kJ})$ of productive energy. For convenience, this requirement can be expressed relative to basal metabolic rate (BMR) calculated from Eq. 5.5 in Kendeigh et al. (1977: 131). Daily BMR for a $3.5-\mathrm{kg}$ crane would be about $209.8 \mathrm{kcal}(878.5 \mathrm{~kJ})$. Thus, fat deposition may require an increase in metabolism of 0.8 BMR. By comparison, if follicle development in cranes takes 10 days and a clutch of two eggs is laid with a day between first and last eggs, then the peak energy requirement during egg formation is about $32 \%$ of final egg energy content (Ricklefs 1974: Table 13). Using an egg weight of $150 \mathrm{~g}$ (Table 2), a caloric value of $\mathbf{1 . 6 5}$ $\mathrm{kcal} / \mathrm{g}$ fresh weight for eggs of precocial land birds (Ricklefs 1974: 182), and a production efficiency of $75 \%$, the peak energy requirement of the female for egg production is $105.6 \mathrm{kcal}$ (442.1 kJ) per day, or about 0.5 BMR. Fat reserves also can be drawn upon to meet maintenance needs during periods when food resources are not adequate.

The acquisition of fat reserves by cranes and geese during spring migration probably evolved as a mechanism to circumvent the uncertainty of foraging conditions, particularly in northern environments that are subject to variable and extreme weather. Deriving a substantial part of the energy cost of migration and reproduction from food resources on staging areas would be advantageous if foraging opportunities were limited at sites north of the Great Plains, or if food resources on wintering grounds were depleted by late winter. $\mathrm{Nu}$ trient reserves would also enhance opportunities to nest earlier, which may be important as some evidence suggests that time available for growth of the young is limited (Baldwin 1977, Harwood 1977). Finally, nutrient reserves sustain northern-nesting geese between the time of arrival and nest initiation during years of delayed snow melt (Barry 1962, Ryder 1970, MacInnes et al. 1974, Mickelson 1975, Davies and Cooke 1983) and serve a similar function to cranes.

Spatial and temporal aspects of migration probably have changed markedly as a result of human alteration of the Great Plains environment. Before agricultural development, food resources were less predictable than at present, causing birds to be more widely spaced during migration, and the magnitude of fat storage probably averaged less and was more variable among years and individuals. Comparative data, however, are lacking for earlier periods. Assuming birds are now typically carrying larger fat reserves, recruitment may have been enhanced, particularly among populations at the peripheral northern edges of the range where energy costs of migration are highest or breeding populations are subject to more variable and extreme weather conditions. Moreover, less experienced birds, if now carrying larger nutrient reserves, may be successfully breeding at an earlier age than in former times. Additional research is needed on the breeding grounds to further examine the significance of condition to recruitment in arctic-nesting populations of Sandhill Cranes.

\section{ACKNOWLEDGMENTS}

Numerous individuals contributed to various aspects of the study. In particular, we thank C. D. Ankney, D. H. Johnson, T. C. Tacha, P. A. Vohs, Jr., and J. R. Serie for constructive comments on earlier drafts of this manuscript and R. Atkins, B. A. Hanson, R. L. Jarvis, D. G. Jorde, T. C. Tacha, and D. C. Martin for their assistance in collection of information. We are 
indebted to C. Jorgenson, Canadian Wildlife Service, Last Mountain Lake, Saskatchewan; C. Strickland and C. Dau, Clarence Rhode NWR, Bethel, Alaska; R. Larson, Alaska Department of Fish and Game; C. R. Frith, U.S. Fish and Wildlife Service, Grand Island, Nebraska; and G. Wingfield, Nebraska Game and Parks Commission, for their support of research at the various study sites. We appreciate statistical support provided by D. H. Johnson, Northern Prairie Wildlife Research Center, and W. D. Warde, Department of Statistics, Oklahoma State University.

\section{Literature Cited}

ANKNEY, C. D. 1982. Annual cycle of body weight in Lesser Snow Geese. Wildl. Soc. Bull. 10: 6064.

—, \& C. D. MACINNES. 1978. Nutrient reserves and reproductive performance of female Lesser Snow Geese. Auk 95: 459-471.

ARCHIBALD, G. W. 1976. The unison call of cranes as a useful taxonomic tool. Unpublished Ph.D. dissertation, Ithaca, New York, Cornell Univ.

Baldwin, J. H. 1977. A comparative study of Sandhill Crane subspecies. Unpublished Ph.D. dissertation, Madison, Wisconsin, Univ. Wisconsin.

BARR, A. J., J. H. GOODKNIGHT, \& J. P. SALL. 1979. SAS user's guide. Raleigh, North Carolina, SAS Institute, Inc.

BARRY, T. W. 1962. Effect of late seasons on Atlantic Brant reproduction. J. Wildl. Mgmt. 26: 19-26.

BoIsE, C. M. 1977. Breeding biology of the Lesser Sandhill Crane (Grus canadensis canadensis L.) on the Yukon-Kuskokwim Delta, Alaska. Unpublished M.S. thesis, Fairbanks, Alaska, Univ. Alaska.

DAvies, J. C., \& F. COOKE. 1983. Annual nesting productivity in Snow Geese: prairie droughts and arctic springs. J. Wildl. Mgmt. 47: 291-296.

HARWOOD, J. 1977. Summer feeding ecology of Lesser Snow Geese. J. Wildl. Mgmt. 41: 48-55.

HoRwITZ, W. 1975. Official methods of analysis, 12th ed. Washington, D.C., Assoc. Off. Anal. Chem.

IVERSON, G. C. 1981. Seasonal variation in lipid content and condition indices of Sandhill Cranes from midcontinental North America. Unpublished M.S. thesis, Stillwater, Oklahoma, Oklahoma State Univ.

Johnson, D. H. 1979. Modeling Sandhill Crane population dynamics. U.S. Dept. Interior, Fish Wildl. Serv., Spec. Sci. Rept. - Wildl. No. 222.

— \& R. E. STEWART. 1973. Racial composition of migrant populations of Sandhill Cranes in the northern plains states. Wilson Bull. 85: 148-162.

KeNDEIGH, S. C., V. R. DOL'NIK, \& V. M. GAVRILOV. 1977. Avian energetics. Pp. 127-204 in Graniv- orous birds in ecosystems (J. Pinowski and S. C. Kendeigh, Eds.). Cambridge, England, Cambridge Univ. Press.

Krapu, G. L., D. E. FaceY, E. K. Fritzell, \& D. H. JOHNSON. 1984. Habitat use by migrant Sandhill Cranes in Nebraska. J. Wildl. Mgmt. 48: 407417.

- K. J. REINECKE, \& C. R. FRITH. 1982. Sandhill Cranes and the Platte River. Trans. North Amer. Wildl. Nat. Resources Conf. 47: 542-552.

LEWIS, J. C. 1979. Field identification of juvenile Sandhill Cranes. J. Wildl. Mgmt. 43: 211-214.

MACINNES, C. D., R. A. DAVIS, R. N. JONES, B. C. LIEFF, \& A. J. PAKULAK. 1974. Reproductive efficiency of McConnell River small Canada Geese. J. Wildl. Mgmt. 38: 686-707.

MCLandress, M. R., \& D. G. Raveling. 1981. Changes in diet and body composition of Canada Geese before spring migration. Auk 98: 6579.

MiCKelson, P. B. 1975. Breeding biology of Cackling Geese and associated species on the YukonKuskokwim Delta, Alaska. Wildl. Monogr. 45.

Pennycuick, C. J., T. Alerstam, \& B. Larsson. 1979. Soaring migration of the Common Crane Grus grus observed by radar and from an aircraft. Ornis Scandinavica 10: 241-251.

Pianka, E. R., \& W. S. Parker. 1975. Age-specific reproductive tactics. Amer. Natur. 109: 453-464.

Raveling, D. G. 1979. The annual cycle of body composition of Canada Geese with special reference to control of reproduction. Auk 96: 234252.

- \& \& H. G. LumSDEN. 1977. Nesting ecology of Canada Geese in the Hudson Bay Lowlands of Ontario: evolution and population regulation. Ontario Ministry Nat. Resources, Fish Wildl. Res. Rept. 98.

RICKLEFS, R. E. 1974. Energetics of reproduction in birds. Pp. 152-292 in Avian energetics (R. A. Paynter, Jr., Ed.). Cambridge, Massachusetts, Publ. Nuttall Ornithol. Club 15.

RYDER, J. P. 1970. A possible factor in the evolution of clutch size in Ross' Goose. Wilson Bull. 82: 513.

STEPHEN, W. J. D. 1967. Bionomics of the Sandhill Crane. Can. Wildl. Serv. Rept. Ser. 2.

Walkinshaw, L. H. 1949. The Sandhill Cranes. Cranbrook Inst. Sci. Bull. 29.

Wiens, J. A., S. G. Martin, W. R. Holthaus, \& F. A. IWEN. 1970. Metronome timing in behavioral ecology studies. Ecology 51: 350-352.

WYPKEMA, R. C. P., \& C. D. ANKNEY. 1979. Nutrient reserve dynamics of Lesser Snow Geese staging at James Bay, Ontario. Can. J. Zool. 57: 213-219. 